\title{
Who Benefits from Ecosystem Services? A Case Study for Central Kalimantan, Indonesia
}

\author{
Aritta Suwarno $^{1}$ (D) Lars Hein $^{1} \cdot$ Elham Sumarga $^{1,2}$
}

Received: 7 April 2015/ Accepted: 24 September 2015/Published online: 14 October 2015

(C) The Author(s) 2015. This article is published with open access at Springerlink.com

\begin{abstract}
There is increasing experience with the valuation of ecosystem services. However, to date, less attention has been devoted to who is actually benefiting from ecosystem services. This nevertheless is a key issue, in particular, if ecosystem services analysis and valuation is used to support environmental management. This study assesses and analyzes how the monetary benefits of seven ecosystem services are generated in Central Kalimantan Province, Indonesia, are distributed to different types of beneficiaries. We analyze the following ecosystem services: (1) timber production; (2) rattan collection; (3) jelutong resin collection; (4) rubber production (based on permanent agroforestry systems); (5) oil palm production on three management scales (company, plasma farmer, and independent smallholder); (6) paddy production; and (7) carbon sequestration. Our study shows that the benefits generated from these services differ markedly between the stakeholders, which we grouped into private, public, and household entities. The distribution of these benefits is strongly influenced by government policies and in particular benefit sharing mechanisms. Hence, land-use change and policies influencing land-use change can be expected to have different impacts on different stakeholders. Our study also shows that the benefits generated by oil palm conversion, a main driver for land-use change in the province, are almost exclusively accrued by companies and at
\end{abstract}

Aritta Suwarno

aritta.suwarno@wur.nl

1 Environmental System Analysis Group, Wageningen University, PO Box 47, 6700 AA Wageningen, The Netherlands

2 School of Life Science and Technology, Institut Teknologi Bandung (ITB), Jalan Ganeca 10, Bandung 40132, Indonesia this point in time are shared unequally with local stakeholders.

Keywords Ecosystem services - Beneficiaries - Benefits · Ecosystem accounting $\cdot$ Ecosystem management

\section{Introduction}

Ecosystem services (ES) are increasingly recognized as a concept that can be used to assess the benefits humans derive from ecosystems in support of ecosystem management (Millennium Ecosystem Assessment (MA) 2005). The concept of ES is broadly defined as the contributions of ecosystems to economic and other human activity (TEEB 2010; UN et al. 2014; Haines-young and Potschin 2013). Benefits from ES are not just a function of ecosystem dynamics but also a function of the socio-economic system (i.e., governance system, markets, and informal land use) (Fisher et al. 2008a). Identification of benefits and beneficiaries from ES is paramount to identify enhanced ecosystem management options (Kettunen et al. 2009).

Several studies have described the concept of beneficiaries and stakeholders of ES for spatial range and specific ecological and economic processes (Hein et al. 2006; TEEB 2010; Bagstad et al. 2014). Studies on how ES benefits received by beneficiaries are altered due to landuse change in several countries have also been conducted from a regional (Tomich et al. 2004; Law et al. 2014) to global scale (Lambin et al. 2003; Howe et al. 2014). However, there is still insufficient insight in how different stakeholders benefit from different types of ES and what this means for ecosystem management (Daily et al. 2009)

The objective of our study is to analyze the benefits of seven ES in Central Kalimantan Province, Indonesia, and 
to examine how these benefits are distributed to different types of beneficiaries. Our study was conducted in three steps: First, we defined the beneficiaries based on the spatial range of ES, related to specific ecological and economic processes (Hein et al. 2006; Bagstad et al. 2014). Second, we calculated the monetary benefits of ES based on ecosystem accounting (UN et al. 2014). Third, we analyzed the benefits received by different types of beneficiaries among others based on existing government regulations in the forestry and agricultural sectors. Further, we analyzed the potential gains and losses of land-use changes through the calculation of total benefits of ES and the estimation of damage costs of $\mathrm{CO}_{2}$ emissions (Interagency Working Group on Social Cost of Carbon 2013).

We use the ecosystem accounting framework as the methodological framework for our study. Ecosystem accounting is a new area of environmental economic accounting, which aims to measure ecosystem capital in a way that is consistent with national accounts (Boyd and Banzhaf 2007; UN et al. 2014; Edens and Hein 2013). Ecosystem accounting provides a framework for analyzing ecosystem condition, ecosystem service flow, and ecosystem assets, using a set of physical and monetary indicators. This approach analyzes the monetary value of production and consumption based on exchange values at 'arm's length.' Contrary to welfare-based valuation approach, it does not include consumer surplus.

The innovative aspects of our study are (1) the implementation of an ecosystem accounting approach to determine the monetary benefits of ES received by the different groups of beneficiaries and (2) linking this information to support ecosystem management. Given the importance of ES benefits in supporting ecosystem management, from the results of this study, we aim to provide valuable input to establish ecosystem management in Central Kalimantan Province.

\section{Methodology}

\section{Study Area}

This study was conducted in Central Kalimantan Province, Indonesia (Fig. 1). The province covers an area of approximately 15.4 million ha of which 12.7 million ha is designated forest (Ministry of Forestry 2011). The total population in 2010 was 2.15 million, with a population density of 14 people $/ \mathrm{km}^{2}$. In terms of local GDP, forest and agriculture (particularly oil palm) are the most important sectors. The forests and peatlands of Central Kalimantan are part of the biodiversity hotspot of Borneo's forest and believed to be among the most species-rich environments in the world (Whitten et al. 2004). They provide vital ecosystem benefits on a local, regional, and global scale including livelihood products (e.g., timber and non-timber products) (Meijaard et al. 2013); cultural services (e.g., nature recreation) (Hernández-Morcillo et al. 2013; Plieninger et al. 2013); and regulating services (e.g., storage of vast amounts of carbon stock) (Paoli et al. 2010; Leh et al. 2013). However, rapid deforestation to further agricultural and silvicultural development, particularly oil palm, in Central Kalimantan has been a salient issue over the last decade. From 2000 to 2008, the province lost approximately 0.9 million ha of forest (Koh et al. 2011; Broich et al. 2011b). Some studies indicated the expansion of oil palm plantation as the main driving factor of deforestation in this province (Boer et al. 2012; Koh et al. 2011). The oil palm expansion in Central Kalimantan Province has been one of the fastest in Indonesia in the period 2000-2010 (Broich et al. 2011a; Koh et al. 2011; Gunarso et al. 2013).

\section{Identification of Beneficiaries and Stakeholders}

ES stakeholders can be defined as any group of individuals who can affect or are affected by the ecosystem's service (Hein et al. 2006). ES beneficiaries benefit from ecosystem goods or services either through active or passive consumption, or through simple appreciation resulting from the awareness of these services (Harrington et al. 2010; Nahlik et al. 2012). The distinction between stakeholder and beneficiary is related to the ability to influence ES provision and the dependency on the ES. Each beneficiary should be considered a stakeholder (Hein et al. 2006; Rastogi et al. 2010), but not all stakeholders are necessarily beneficiaries.

The ES benefits vary depending on the type of their individual characteristics, spatial scale, and distance between production area and the location of beneficiaries (Fisher et al. 2008b; Bagstad et al. 2014). In this study, we grouped beneficiaries based on spatial extent and bio-economic process to be consistent with the beneficiaries' concept in the System of National Accounts (SNA). The beneficiaries of ES are then grouped into (1) private (large companies, small medium enterprises (SMEs), smallholder with hired labor); (2) public (governmental agencies at various levels); and (3) household entities as presented in Table 1.

In this study, we selected six provisioning and one regulating services which are important for the livelihood of local people and the economic development in the district and the province. These seven ES include (1) timber production; (2) rattan collection; (3) jelutong resin (Dyera costulata) collection; (4) rubber (Hevea brasiliensis) production (based on permanent agroforestry system); (5) oil palm production on three management scales (company, plasma farmer and independent smallholder); (6) upland paddy production; and (7) carbon sequestration. In this study, we also include the analysis of nature recreation in Tanjung Puting National Park (Taman Nasional Tanjung 


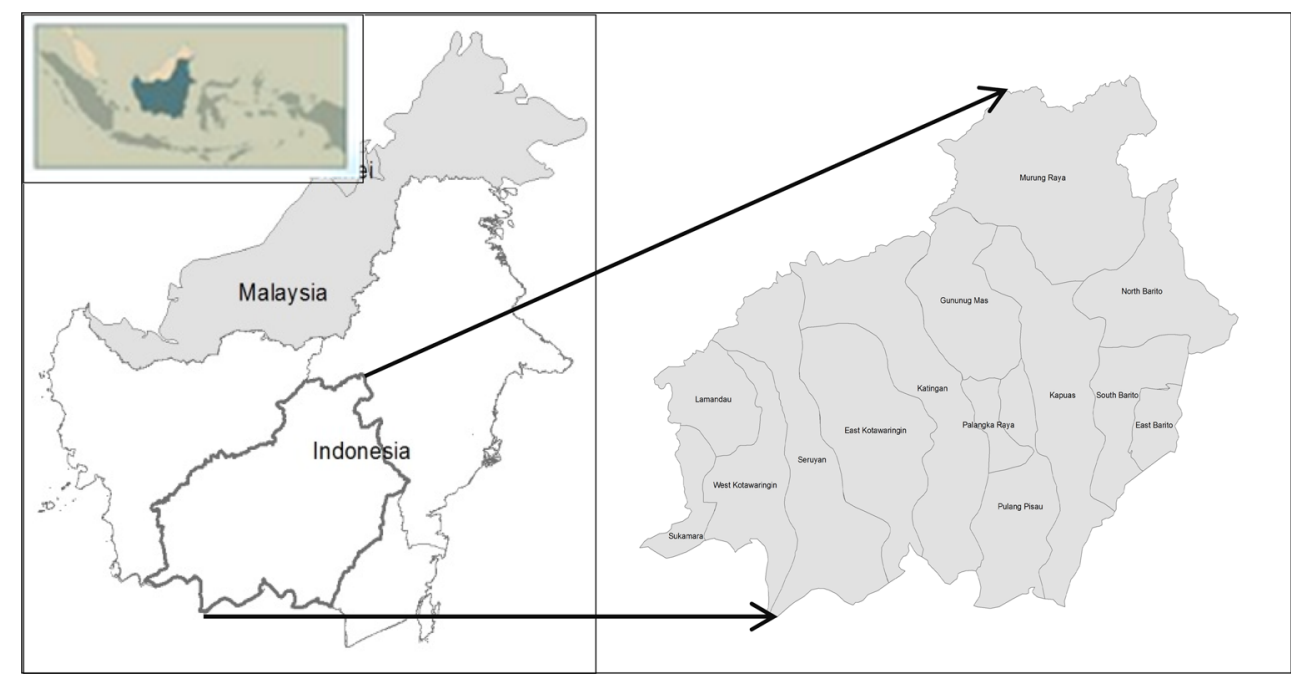

Fig. 1 Case study area

Puting-TNTP) due to its importance for the livelihood of local people living around this national park. Further, we also include the analysis on orangutan habitat as a global concern.

\section{Valuation of Ecosystem Services}

The benefits of the provisioning services in this study are assessed in monetary terms. We applied the valuation approach of ecosystem accounting (UN et al. 2014). Ecosystem accounting is the approach used to measure ecosystem capital in a way that is consistent with the national accounts (UN et al. 2014; Edens and Hein 2013). Ecosystem accounting involves an extension of the production boundary of the SNA to assess the capital of ecosystems based on their flow into economic and other human activities (UN et al. 2014; Hein et al. 2015). This approach allows for the inclusion of a broader set of ecosystem service types (i.e., regulating services) and the natural growth of biological assets in the accounts (UN et al. 2014).

In this research, we analyzed the net benefits of ES that are traded in the market (timber production, rattan collection, jelutong resin collection, agroforestry rubber production, oil palm production, and paddy production) expressed as an annual resource rent (RR). The annual RR has been valued by analyzing the market price and deducting the total costs (intermediate, employment, and user production cost) (Edens and Hein 2013). Considering the different time dimensions of the investment in ecosystem capital, we applied an ordinary annuity approach to calculate the annual RR of oil palm and agroforestry rubber production to make these services comparable. The annual RR was calculated from the net present value (NPV), which is the sum of the discounted revenues $R$ minus cost $C$ :

$\mathrm{NPV}=\sum_{t=1}^{T}\left(R_{t}-C_{t}\right)(1+i)^{-t}$

The NPV can be transformed into an annual payment $A$ :

$A=\mathrm{NPV} \cdot \frac{i(1+i)^{T}}{(1+i)^{T}-1}$

where $A$ is annual RR, $T$ is the life time of the investment, and $i$ is the discount rate, which is set at $10 \%$ in our study (Based on Sumarga et al. (2015)).

In this study, we also analyzed the benefits of carbon sequestration (as the regulating service) based on the marginal social damage costs (Tol 2005) expressed as the social cost of carbon (SCC). The SCC is "an estimate of the monetized damages associated with the increment increase in carbon emissions in a given year" (Interagency Working Group on Social Cost of Carbon 2013). Since these marginal damage costs give a present value of future damage cost estimates, the discount rate plays an important role in determining the marginal damage costs. The SNA (UN et al. 2014) indicates that discounting should take place with market discount rates. In order to capture the public goods character of carbon damages, we apply a social discount rate of $3 \%$ (Interagency Working Group on Social Cost of Carbon 2013). Consequently, we used an SCC value for 2010 at USD 32/ton $\mathrm{CO}_{2}$ that is equivalent to $€ 24 /$ ton $\mathrm{CO}_{2}$ ( $€ 88 /$ ton $C$ ) with an exchange rate of USD $\$ 1.33$ for $€ 1$ (average in 2010).

The main data and information used in this study were mostly obtained from the previous studies (2008-2010) and field work in 2012, as presented in Table 2. These secondary data include the information for economic analysis, 


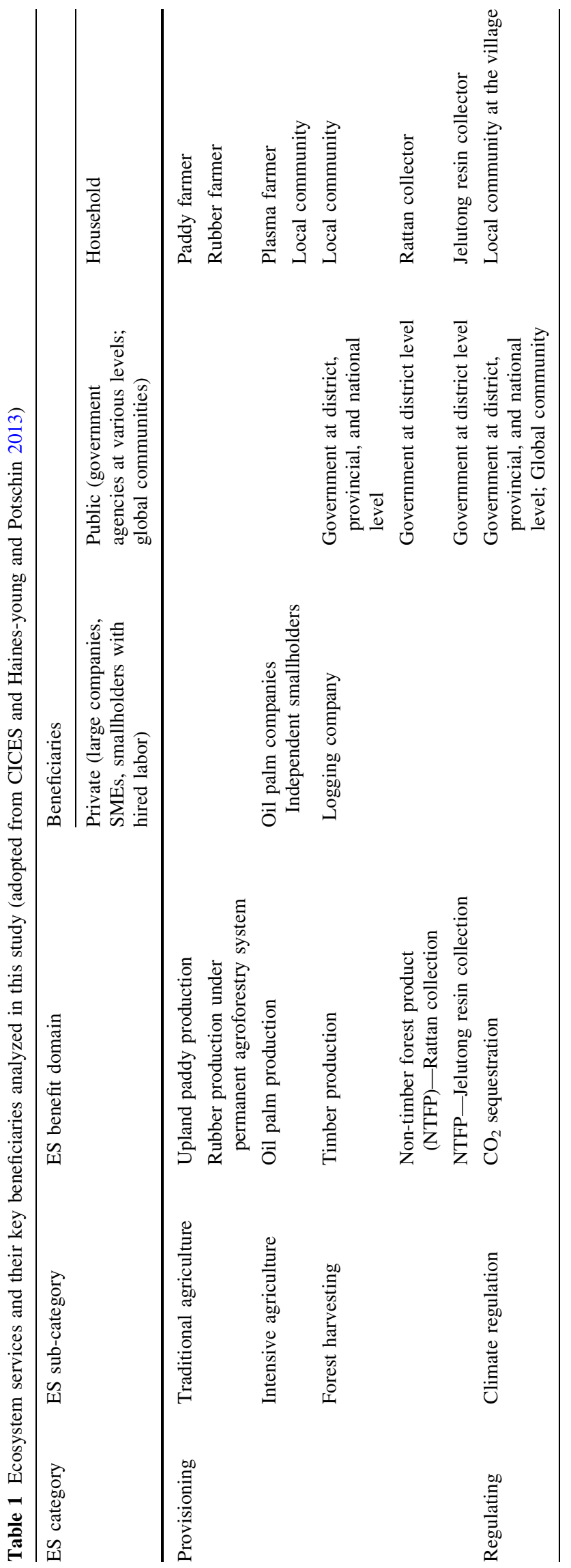

the potential production of each service per year (yields), and macroeconomic parameters in 2010.

\section{Allocation of Benefits to Different Types of Beneficiaries}

Beneficiaries receive benefits from ES through different mechanisms. The allocation of benefits from ES received by beneficiaries was analyzed to explore the way benefits are shared between private, public, and household beneficiaries based on the framework presented in Fig. 2. The allocation of benefits to private entities was based on the annual net benefits. The allocation of benefits to household entities was based on annual benefits plus wages. The shares of the benefits public entities received from ES were calculated based on relevant public finance regulations applied at different levels of government. For instance, the share of benefits from timber production that public entities received at the district level was based on Government Regulation (PP) No. 55/2005 concerning the procedure for governing timber and non-timber forest products and Law No. 33/2004 concerning financial aspects of decentralization. These regulations determine taxes, including tax on timber and a land tax, and fees for extracting timber and non-timber forest products both from natural forests and plantation forests. Public finance regulations covered in this study are presented in Table 3.

\section{Potential Benefits in Different Land Uses}

We explored the total monetary benefits private, public, and household beneficiaries received from different land uses. The total monetary benefits for each land-use type were derived from the sum of the monetary benefits beneficiaries received. The calculation of potential loss from carbon emissions was conducted based on marginal damage costs, capturing the cost of emitting a ton of carbon $\left(\mathrm{CO}_{2}\right)$. We applied the social cost of carbon (SCC) value for 2010 at $€$ 24/ton $\mathrm{CO}_{2}$, based on an assumed discount rate of $3 \%$ (Interagency Working Group on Social Cost of Carbon 2013).

\section{Results}

\section{Monetary Benefits Generated by Ecosystem Services}

\section{Provisioning Services}

Compared to the other provisioning services that we analyzed, oil palm production provides the highest net benefit per ha; however, it also leads to significant societal costs related to $\mathrm{CO}_{2}$ emissions, in particular when oil palm is cultivated on peatland. Oil palm production on peatland 
Table 2 Details of the data used in this study

\begin{tabular}{|c|c|c|}
\hline Ecosystem service & Remark & Sources \\
\hline Timber production & $\begin{array}{l}\text { Financial report } \\
\text { Performance of logging activities }\end{array}$ & Two logging companies; Setiawan et al. (2011) \\
\hline Rattan collection & $\begin{array}{l}\text { Economic analysis } \\
\text { Potential yield/ha }\end{array}$ & Iwan (2008); Martoniady (2009) \\
\hline Jelutong resin collection & $\begin{array}{l}\text { Economic analysis } \\
\text { Potential yield/ha }\end{array}$ & Sapiudin (2009); Budiningsih and Effendi (2013) \\
\hline Agroforestry rubber production & $\begin{array}{l}\text { Economic analysis } \\
\text { Potential yield/ha }\end{array}$ & (Herman and Las 2009); Suyanto et al. (2009) \\
\hline Upland paddy production & $\begin{array}{l}\text { Economic analysis } \\
\text { Potential yield/ha }\end{array}$ & Nugroho (2008); Yandi (2008) \\
\hline Oil palm production & $\begin{array}{l}\text { Economic analysis } \\
\text { Potential yield/ha }\end{array}$ & $\begin{array}{l}\text { Two oil palm companies; Iksan and Abdussamad } \\
\text { (2010); Ismail (2010); Boer et al. (2012) }\end{array}$ \\
\hline Carbon sequestration & $\begin{array}{l}\text { Potential } \mathrm{CO}_{2} \text { emission } \\
\text { Social cost of carbon }\end{array}$ & $\begin{array}{l}\text { Sanchez (2000); Agus et al. (2009); Hooijer et al. } \\
\text { (2010); Lim et al. (2012); Carlson et al. } \\
\text { (2012b); Carlson et al. (2012c); Interagency } \\
\text { working group on social cost of carbon (2013); } \\
\text { Agus et al. (2013); Gunarso et al. (2013) }\end{array}$ \\
\hline
\end{tabular}

generates an annualized resource rent for company, smallholder, and plasma farmer of $€$ 683/ha/year, $€ 395 /$ ha/ year and $€ 451 /$ ha/year, while on mineral soil, this is $€$ 902/ha/year, $€ 537 /$ ha/year, and $€ 765 /$ ha/year, respectively. This difference reflects that the production costs, in particular for plantation establishment, are higher for peatland.

Timber production, both on peatland and mineral soil, generates a resource rent of, on average, $€ 30 /$ ha/year. This relatively low value indicates that most of the forests in Central Kalimantan have been heavily logged in the past and that many of the commercial timber species (e.g., Gonystylus bancanus and Eusideroxylon zwageri) have already been harvested. The benefits from other forest products, in particular rattan and jelutong resin are considerably higher, on average, for the forest areas in Central Kalimantan, $€ 82 /$ ha/year for rattan, and $€ 83 /$ ha/year for jelutong. However, generation of the resource rent from these products is concentrated in the areas where there is active management and harvest of rattan or jelutong. In these areas, production can be as high as 1.3 ton/ha/year for rattan and 0.5 ton/ha/year for jelutong (in case enrichment planting of rattan or jelutong trees respectively has been carried out) (Sapiudin 2009). The resulting resource rent generated per ha, in these cases, amounts to $€ 110 /$ ha/year for rattan, respectively, $€ 157 /$ ha/year for jelutong.

Rubber production captured in this study is produced under a permanent agroforestry system with an average yield of about $0.67 \mathrm{ton} / \mathrm{ha} / \mathrm{year}$ for the mineral soil and 0.54 ton/ha/year for the peatland (Suyanto et al. 2009). Agroforestry rubber production on the mineral soil provides a net benefit of $€ 112 /$ ha/year, while production on peatland provides a net benefit $€ 47 /$ ha/year.

Paddy is the most important food crop produced in this province. It is mainly grown by transmigrants who originally came from Java or Sumatra, although traditionally the Dayak 'Ngaju' in the provinces of Central and West Kalimantan have been practicing swidden rice cultivation for many generations (de Jong 1995). The average production of paddy in this area is about 2.2 ton/ha/year on the mineral soil and 1.7 ton/ha/year on the peatland. Paddy production generates an average resource rent of $€ 287 /$ ha/year on mineral soil and $€ 184 /$ ha/year on peatland. The large majority of paddy production in Central Kalimantan is used for local consumption.

Details of the results of the analysis on net benefits from provisioning services are presented in Table 4.

\section{Regulating Service (Carbon Sequestration)}

The result of our analysis on monetary benefits from carbon sequestration shows that conversion of forest areas on the peatland and mineral soil to oil palm plantation provides the lowest benefits due to high $\mathrm{CO}_{2}$ emissions. Potential $\mathrm{CO}_{2}$ emission from converting forest to oil palm on the peatland is about 85 ton/ha/year and on mineral soil is about 25 ton/ha/year. The resulting monetary benefits generated per ha, in these cases, amount to $€-2040 / \mathrm{ha} /$ year for the peatland and $€-600 /$ ha/year for mineral soil, respectively. These results show that converting forest area to oil palm plantation will increase the potential $\mathrm{CO}_{2}$ emission, which have become a global public concern. 


\section{Income generated from ES}

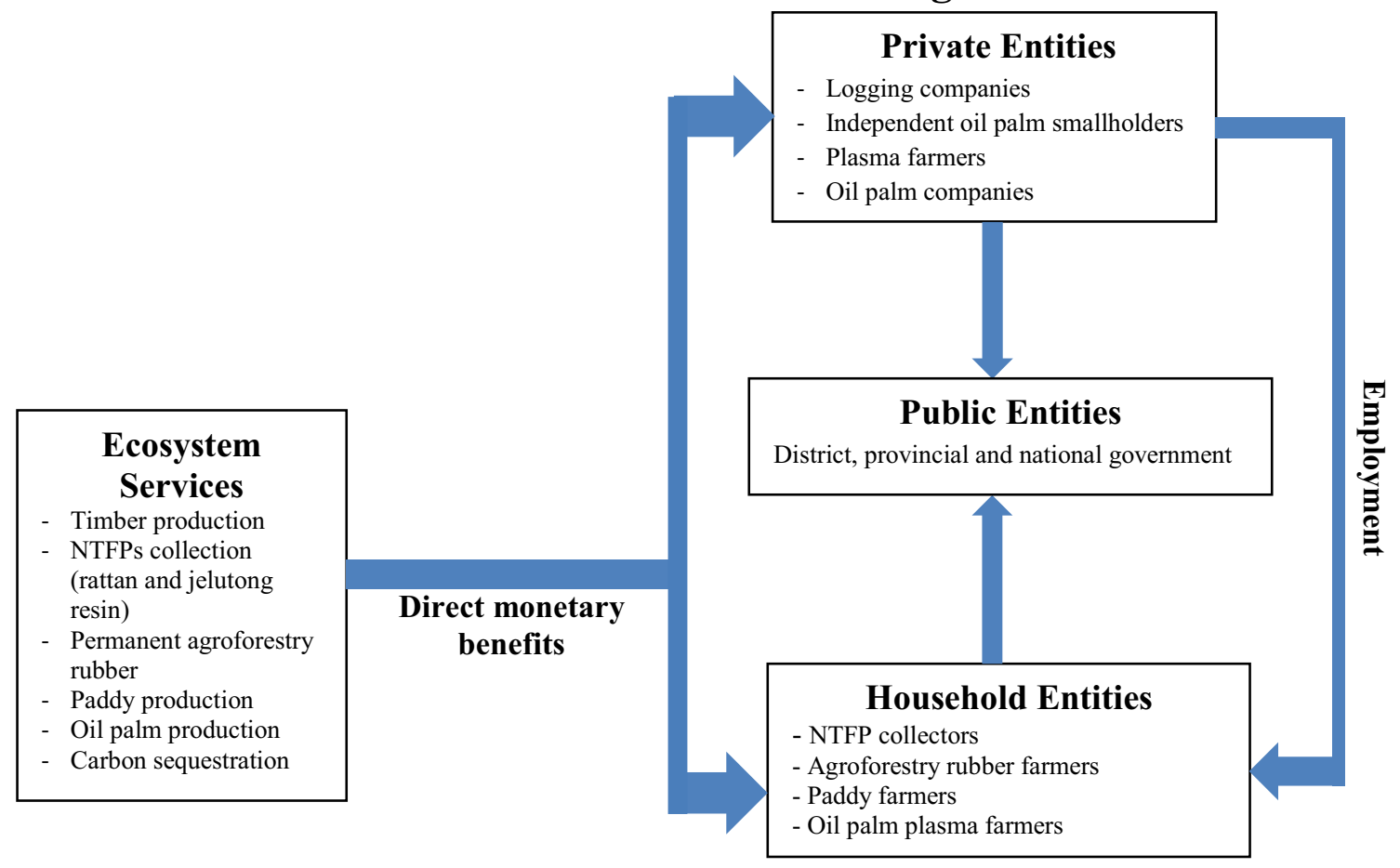

Fig. 2 Income generated from ES by different groups of ES beneficiaries

Table 3 Legal framework in relation to taxes, provisioning, royalties, and benefit distribution

\begin{tabular}{ll}
\hline Service & Legally binding on public policies \\
\hline Timber & Law (UU) No. 33/2004 \\
& $\begin{array}{l}\text { Government Regulation (PP) No. 55/2005 } \\
\text { Government Regulation (PP) No. 55/2005 } \\
\text { Rattan }\end{array}$ \\
$\begin{array}{l}\text { Jelutong resin } \\
\text { Permanent } \\
\text { agroforestry rubber } \\
\text { Paddy }\end{array}$ & Government Regulation (PP) No. 55/2005 \\
Oil Palm & Government Regulation No. 7/2007 \\
\hline
\end{tabular}

Detail on potential $\mathrm{CO}_{2}$ emissions and SCC analyzed in this study is presented in Table 5 .

\section{Benefits from Employment}

The monetary benefits beneficiaries receive from ES as employees or household entities are defined by the number of person working days per ha and wages per person per working day. In this study, we are concerned with farmers' paddy and oil palm production (under plasma) based on the household system, which mainly 'employs' family members. Ecosystem accounting required deducting actual or implemented cost for labor, also in case the labor is provided by the farmer himself (UN et al. 2014; Obst et al.
2015). In order to keep the calculation in line with the ecosystem accounting methodology, we calculated the employment costs for these services based on the number of person days of family labor used per ha per year and multiplied this by the local average daily wage.

The results of our analysis show that in terms of the number of working days per ha, oil palm plantation under companies provides the highest number of person days (107 person days/ha/year), while timber production provided the lowest ( 0.7 person days/ha/year). On the other hand, in terms of wages, timber production provides the highest wages ( $€$ 13/person/day), while the lowest wages are provided by paddy production ( $€ 3$ /person/day). The details of the benefits beneficiaries received for employment are presented in Table 6 .

\section{Potential Net Benefits and Loss of ES Received by Beneficiaries from Different Types of Land Use}

The change of forest to other land use will influence the supply of ES. Our analysis shows that the change of forest to other land use, particularly oil palm plantation, can potentially increase income for the sectors households and industry. However, it is important to note that within the household sector there may be important differences between costs and benefits accruing to different groups of people. For example, Dayak groups have in some cases 
Table 4 Annual resource rent from provisioning services

\begin{tabular}{|c|c|c|c|c|c|c|c|c|c|}
\hline \multirow{2}{*}{$\begin{array}{l}\text { Soil } \\
\text { type }\end{array}$} & \multirow{2}{*}{$\begin{array}{l}\text { Ecosystem } \\
\text { services }\end{array}$} & \multirow{2}{*}{$\begin{array}{l}\text { Yield } \\
\text { (m3/ha/year; } \\
\text { ton/ha/year) }\end{array}$} & \multirow{2}{*}{$\begin{array}{l}\text { Price } \\
(€ / \mathrm{m} 3 ; \\
€ / \text { ton })\end{array}$} & \multirow{2}{*}{$\begin{array}{l}\text { Gross } \\
\text { revenue } \\
\text { (€/ha/year) }\end{array}$} & \multicolumn{2}{|c|}{ Production cost ( $€ /$ ha/year) } & \multirow{2}{*}{$\begin{array}{l}\text { Value } \\
\text { added } \\
\text { (€/ha/year) }\end{array}$} & \multirow{2}{*}{$\begin{array}{l}\text { Labor cost } \\
(€ / \text { ha/year })\end{array}$} & \multirow{2}{*}{$\begin{array}{l}\text { Resource } \\
\text { rent } \\
(€ / \text { ha/year) }\end{array}$} \\
\hline & & & & & $\begin{array}{l}\text { Intermediate } \\
\text { cost } \\
\text { (€/ha/year) }\end{array}$ & $\begin{array}{l}\text { User cost } \\
\text { of fixed } \\
\text { assets } \\
(€ / \text { ha/year })\end{array}$ & & & \\
\hline \multirow[t]{7}{*}{ Peatland } & Timber & 0.86 & 118 & 101 & 62 & 0 & 39 & 9 & 30 \\
\hline & Jelutong & 0.28 & 342 & 96 & 6 & 0 & 90 & 7 & 83 \\
\hline & Rubber & 0.54 & 500 & 270 & 7 & 0 & 263 & 216 & 47 \\
\hline & Oil palm (company) & 19 & 123 & 1997 & 778 & 112 & 1107 & 424 & 683 \\
\hline & Oil palm (smallholder) & 12 & 123 & 1278 & 403 & 164 & 711 & 316 & 395 \\
\hline & $\begin{array}{l}\text { Oil palm } \\
\quad \text { (plasma farmer) }\end{array}$ & 16 & 123 & 1697 & 701 & 189 & 807 & 356 & 451 \\
\hline & Paddy & 1.7 & 238 & 405 & 80 & 6 & 319 & 135 & 184 \\
\hline \multirow[t]{7}{*}{ Mineral soil } & Timber & 0.86 & 118 & 101 & 62 & 0 & 39 & 9 & 30 \\
\hline & Rattan & 0.79 & 145 & 115 & 16 & 0 & 99 & 17 & 82 \\
\hline & Rubber & 0.67 & 500 & 335 & 7 & 0 & 328 & 216 & 112 \\
\hline & Oil palm (company) & 19 & 123 & 1997 & 637 & 84 & 1276 & 374 & 902 \\
\hline & Oil palm (smallholder) & 12 & 123 & 1278 & 338 & 123 & 817 & 280 & 537 \\
\hline & $\begin{array}{l}\text { Oil palm (plasma } \\
\text { farmer) }\end{array}$ & 16 & 123 & 1697 & 471 & 142 & 1084 & 318 & 766 \\
\hline & Paddy & 2.22 & 238 & 528 & 87 & 7 & 434 & 147 & 287 \\
\hline
\end{tabular}

Table 5 Potential $\mathrm{CO}_{2}$ emissions and its Social Cost of Carbon (SCC)

\begin{tabular}{llll}
\hline Soil type & Land use & $\begin{array}{l}\mathrm{CO}_{2} \text { emission } \\
\text { (ton/ha/year) } \\
(- \text { indicates emission, } \\
+ \text { is sequestration) }\end{array}$ & $\begin{array}{l}\text { SCC } \\
\text { Peatland }\end{array}$ \\
& Forest & 19.4 & -14.4 \\
& Agroforestry & -85 & -345.6 \\
& Oil palm plantation & -27.3 & -640 \\
Mineral soil & Agricultural land & 13.6 & 326.4 \\
& Forest & 7.3 & 175.2 \\
& Agroforestry & -25 & -600 \\
& Oil palm plantation & 7.3 \\
\hline
\end{tabular}

sold (sometimes very cheaply) or lost their land to independent smallholders or oil palm companies. In this case, they have lost the opportunity of gaining benefits from other ES without adequate compensation, even though they may still receive benefits from oil palm production through employment However, not all local people can be employed on the plantations (McCarthy et al. 2012; Palupi 2014) and wages for casual labor are relatively low (€ 3.5/day; see Table 6).

The conversion of forest to oil palm plantation, particularly on the peatland, generates high $\mathrm{CO}_{2}$ emissions. Estimates for the $\mathrm{CO}_{2}$ emissions resulting from oil palm development on peatland range from 875 to 2125 ton/ha for the total period of 25 years, equal to $35-85$ ton/ha/year (Herman and Las 2009; Agus et al. 2010; Hooijer et al. 2010; Lim et al. 2012; Carlson et al. 2012a, b; Couwenberg and Hooijer 2013). This results in social costs ranging from $€-840 /$ ha/year to $€-2040 /$ ha/year. On the other hand, a permanent agroforestry system on peatland may generate lower monetary benefits but also leads to much lower $\mathrm{CO}_{2}$ emissions. $\mathrm{CO}_{2}$ emissions from agroforestry systems strongly depend on type of agroforestry and drainage depth (if any drainage is applied). They vary from a small capture of carbon to net $\mathrm{CO}_{2}$ emissions of 14.4 ton $\mathrm{CO}_{2} /$ ha 
Table 6 Benefits beneficiaries received for employment

\begin{tabular}{lllc}
\hline $\begin{array}{l}\text { Ecosystem } \\
\text { services }\end{array}$ & $\begin{array}{l}\text { Number of } \\
\text { person days/ha }\end{array}$ & $\begin{array}{l}\text { Wages } \\
(€ / \text { person-day })\end{array}$ & $\begin{array}{r}\text { Wages } \\
(€ / \text { ha })\end{array}$ \\
\hline Timber & 0.7 & 13 & 9 \\
Rattan & 3.1 & 5.4 & 17 \\
Jelutong resin & 1.2 & 5.8 & 7 \\
Rubber & 54 & 4 & 216 \\
Paddy & 49 & 3 & 147 \\
Oil palm & & & \\
Smallholder & 80 & 3.5 & 280 \\
Plasma & 91 & 3.5 & 318 \\
Company & 107 & 3.5 & 374 \\
\hline
\end{tabular}

(average from Agus et al. 2013; Sanchez 2000). We do not consider methane emissions from paddy fields in our study since all paddy fields in the study area are upland fields that do not cause methane emissions (Inubushi et al. 2003; Hadi et al. 2012). The results of our analysis on potential annual benefits received by private, public, and household entities, as well as potential losses due to the estimated $\mathrm{CO}_{2}$ emissions, are presented in Table 7.

\section{Discussion}

\section{Who Benefits from Ecosystem Services?}

People obtain benefits from ecosystems in different ways. Our analysis of six provisioning and one regulating service in Central Kalimantan Province shows the monetary benefits received by different stakeholders. This study shows that upland paddy production provides the highest monetary benefits to household entities, while private and public entities receive most from oil palm and timber production. This study also shows how the monetary benefits from timber, NTFPs (rattan and jelutong resin), and agroforestry rubber are distributed to private, household, and public entities.

NTFPs and agroforestry rubber are the main source of local livelihoods in Central Kalimantan (Meijaard et al. 2013; Abram et al. 2014). However, the decrease in forest quality and agroforestry rubber areas has consequently decreased the stock of NTFPs and agroforestry rubber, and influences the monetary benefits received by household and public entities.

Oil palm production is a profitable venture in the case study area, in spite of fluctuations in market prices. Stakeholders have increasingly converted forest and agroforestry area to oil palm plantation, and have neglected the NFTPs and agroforestry rubber. The local government has seen oil palm plantation as an opportunity for economic development in their area through the increase in the number of jobs and also local people see it as an employment opportunity. In addition, the national target for CPO production has also supported this interest and caused an increase in the expansion of oil palm plantation in Indonesia.

The expansion of oil palm in Indonesia has been criticized locally and internationally. One of the criticisms in economic and social terms is related to the disadvantaged position of local communities when negotiating land transactions and business arrangements (Sirait 2009; McCarthy and Cramb 2009; Rist et al. 2010; Larsen et al. 2012; Obidzinski et al. 2012; Budidarsono et al. 2013; Dehen et al. 2013). An assessment of the characteristics of the private entities connected to oil palm production reveals that this activity is dominated by stakeholders with a high capital outlay, due to the high cost of establishing oil palm plantations. The cost of establishing an oil palm plantation in the first 3 years, on an independent smallholder scale, can be between $€ 428 /$ ha/year and $€ 862 / \mathrm{ha} /$ year (Iksan and Abdussamad 2010; Boer et al. 2012). The break-even point can only be achieved with a minimum of 3 ha, assuming that smallholder farmers sell the fresh fruit bunches (FFB) at the farm gate (Boer et al. 2012; Budidarsono et al. 2013). Smallholders with the capital to establish oil palm are likely middle or upper class individuals with a close relationship with either an oil palm company or a key person at the district, provincial, or national level (Rist et al. 2010; Larsen et al. 2012; Dehen et al. 2013). Hence, the monetary benefits from oil palm production are mostly gained by companies and the elite with only a small share of the benefits going to the local communities and government through public regulations.

At the same time, some of the costs associated with palm oil production (traffic, road maintenance, and local externalities of oil palm plantations such as reduced access to the forest) occur at the district level. In addition, the rapid expansion of oil palm plantation in Central Kalimantan has also increased social conflicts associated with labor allocation (Rist et al. 2010; Dehen et al. 2013). Oil palm cultivation requires special skills that are more frequent among migrant smallholders with prior exposure to oil palm rather than for the local community with no prior experience. This has caused the exclusion of local people from this kind of work. The change in regulations governing partnerships in oil palm plantations, due to the establishment of Ministry of Agriculture Regulation No. 98/2013 that replaced Regulation No. 5/2011, has also created problems related to tenure and arrangements concerning plasma systems (McCarthy et al. 2012; Potter 2012). According to this new regulation, the plantations can no longer allocate $20 \%$ of their concessions for plasma farming; they must find this outside their concession. This regulation is extremely difficult to implement in Central 


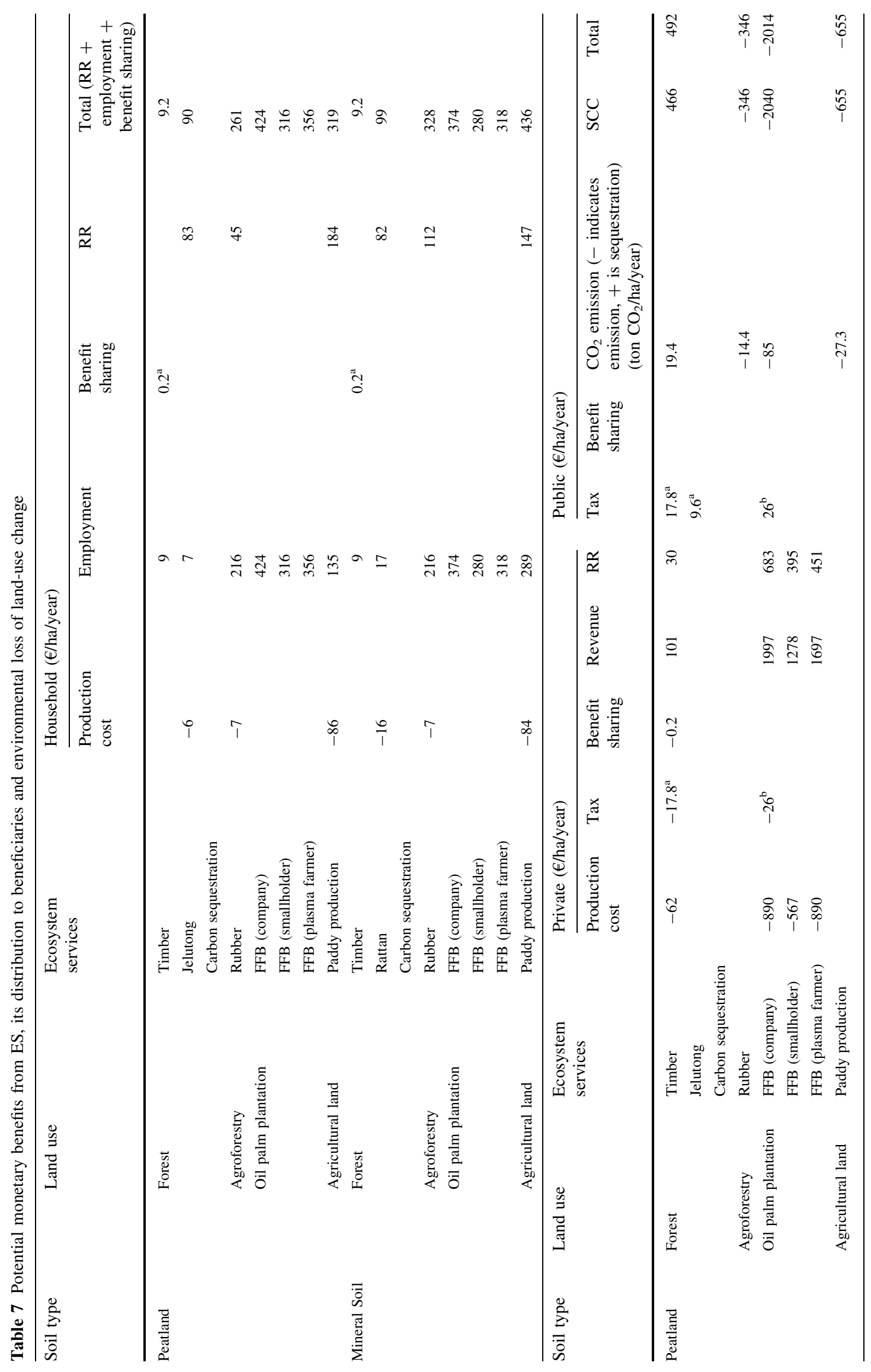




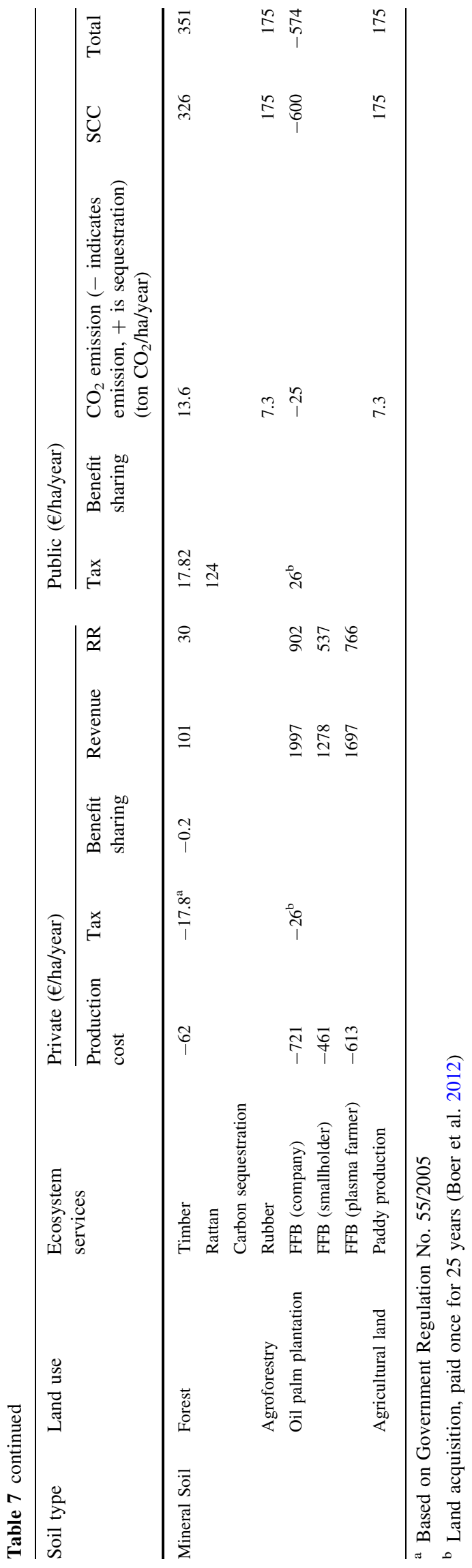

Kalimantan Province, since most of the recent transmigrants have become independent smallholders. Hence, plantations prefer to buy up Dayak land for inadequate levels of compensation to meet this regulation, which eliminates the opportunity for Dayak groups to receive other ES benefits, other than casual day labor (Palupi 2014). Problems related to environmental degradation have also increased due to the impact of oil palm expansion on deforestation, soil subsidence, hydrology, and climate change (Germer and Sauerborn 2007; Larsen et al. 2012; Yamamoto and Takeuchi 2012; Carlson et al. 2012b), see also the related work of Sumarga and Hein (2014) and Sumarga et al. (2015) in the same area.

\section{Potential Benefits and Losses When Changing a Forest Ecosystem to a Monoculture Plantation}

ES trade-offs arise from management choices made by humans, who intentionally change the type, magnitude, and relative mix of services provided by an ecosystem. Tradeoffs occur when the provision of one ecosystem service is reduced as a consequence of increased the use of another (Rodríguez et al. 2006). A common pattern of provisioning services is that they compete with each other (Tilman et al. 2002; Rodríguez et al. 2006). For example, an increase in oil palm production will reduce the timber and NTFPs production when oil palm is planted and replaces the forest.

Our analysis on potential benefits and losses in different land uses shows that the conversion of forest to oil palm plantation will increase the monetary benefits received by private and household entities, and decrease the monetary benefits received by public entities due to the absence of a regulation governing the FFB. The conversion of forest to oil palm plantation will also reduce the potential monetary benefits from nature recreation. Our interview with stakeholders in TNTP shows that this national park has generated the highest number of visitors (since visitors have been recorded) among all the national parks in Central Kalimantan. In 2010, the number of foreign visitors reached 8422 and domestic visitors 2343. The report from TNTP shows that in 2010, this national park has contributed $€ 612,578$ to the local economy and $€ 51,471$ to the national government (BTNTP 2012). However, the establishment of oil palm plantation around the buffer zone of this national park has become a salient issue that might reduce the environmental quality of TNTP and consequently influence the number of visitors. Our interviews with 50 boat operators and 150 tourists, during the period July to September 2012, also show the high concern about the water quality of the Sekoyer River. The reduction in water quality is due to the recent establishment an oil palm plantation (in 2011) in the buffer zone of TNTP. Most of the tourists (125 of 150) stated that they were upset about 
this environmental condition and most of the boat operators (35 of 50) thought that it would reduce the number of tourists visiting this national park in the future.

In environmental terms, converting forest to oil palm plantation will increase the environmental risk of deforestation, soil subsidence and carbon emissions, as well as decrease of biodiversity and the quality and quantity of river water (Germer and Sauerborn 2007; Hooijer et al. 2012; Agus et al. 2013; Azhar et al. 2014). As we show, the social costs related to $\mathrm{CO}_{2}$ emissions from oil palm on peat are higher than the total benefits private and public beneficiaries receive from oil palm production (cf. Sumarga et al. 2015).

The conversion of forest to oil palm plantation will also reduce the habitat of many endangered species such as the orangutan. The orangutan is an endangered species listed in appendix 1 of the convention on international trade in endangered species (CITES) for flora and fauna. It is Asia's only remaining great ape, living only in Borneo and Sumatera (Nellemann et al. 2007). Moreover, Central Kalimantan is likely to have the world's largest population of orangutan at the provincial level. The total population of wild orangutan in this province is about 33,000 individuals and $61 \%$ of them occur in protected areas (Wich et al. 2008). Based on the unique place of Central Kalimantan as home to some $50 \%$ of the remaining orangutan in the wild, maintaining the habitat for this species should be of special concern in particular in this province.

\section{Policy Implications}

The establishment of policy instruments in natural resource management is vital when governing the distribution of ES benefits to private, public, and household entities. These instruments may not only ensure the sustainability of local livelihoods but also secure environmental funding that could be used to explore alternative and sustainable sources of financing ES management (Kettunen et al. 2009). For example, a reforestation fund from timber production could be used to cover reforestation costs of degraded forest areas.

Forest degradation and biodiversity loss has increased the awareness of the need to improve sustainable forest and land management in Indonesia. In response to that awareness, the government of Indonesia has released various regulations on sustainable forest management to govern the extraction of timber and NFTPs (including carbon sequestration), as well as nature recreation. The extraction of timber, both from natural forest and/or plantation forest, must be conducted according to certain regulations concerning reforestation funds, taxes on forest resources, and fees for concession permits. The national government also released a regulation governing the system for NTFPs collection and tariffs for entering a national park.

Considering the rapid deforestation and expansion of oil palm in Indonesia, it is very important to analyze the contribution of ES to forest ecosystems. Our analysis shows that timber and NTFPs have provided the highest benefits to public entities through Government Regulation No. 55/2005 on sustainable forest management. This regulation governs reforestation funds, taxes on forest resource, and fees for timber concession (both from natural forest and/or plantation forest) and NTFPs collection. However, the change in the value added tax (VAT) status of agricultural products in Government Regulation No. $12 / 2001$ has eliminated any contribution from oil palm production to the public budget. In this regulation, FFB is listed as a non-taxable agricultural products, and the plantations (both companies and households) are only required to pay the cost of obtaining land cultivation rights (Hak Guna Usaha-HGU) of about $€ 208$ to $€ 333$ /ha for 25 years and a land and building tax (PBB) of about $€ 10$ to $€ 15 /$ ha/year (Boer et al. 2012).

The public finance regulation applied to the palm oil sector is the tax on exporting CPO, kernel palm oil (KPO) and their derivative products. The export tax on these products is governed by the Ministry of Finance Regulation No. 67/Pmk.011/2010, based on Annex No II of the Ministry of Finance Regulation No. 223/Pmk.011/2008. The export tax is calculated in a progressive way, based on international prices of these products in cost, insurance and freight (CIF) Rotterdam. The export tax on CPO, KPO, and its derivative products is amended annually by the national government to increase the national revenue from the palm oil sector. However, this revenue is not distributed to the district and provincial governments. Considering the high cost of maintaining the infrastructure in the district, particularly roads (due to heavy loads transporting CPO and $\mathrm{KPO}$ ), a request for a proportion of the income, from the import/export tax on $\mathrm{CPO}$ and $\mathrm{KPO}$, to be directed to the producing district, was released by the Association of Indonesian District Government (Asosiasi Pemerintah Kabupaten Seluruh Indonesia-APKASI) at their meeting on 5 July 2014.

In order to support the sustainable production of agricultural products and address the environmental problems caused by the conversion of forest to monoculture plantations, there is a need to set up another policy instrument to govern the benefit distribution from the agricultural sector, particularly oil palm. This policy instrument should capture environmental aspects on sustainable oil palm production and secure the rights of local and poor people who depend heavily on forest ecosystems in which the forests area are converted to oil palm plantation. It is also important to 
revisit the financial regulation in this sector, to ensure that the monetary benefits received by public entities.

\section{Conclusions}

This study assesses and analyzes the monetary benefits of seven ES in Central Kalimantan and how these benefits are allocated to different types of beneficiaries. This study shows that oil palm production provides the highest monetary benefits to private entities and lowest to public entities and local indigenous households, particularly Dayak groups. The benefits generated by this service are almost exclusively accrued by companies with at this point in time very little if any benefit sharing with local stakeholders, in particular when the local costs of oil palm expansion are considered. Considering oil palm plantation establishment as one driver of land-use change, there is a need to set up additional policy instruments to govern the sustainability of this product and to ensure that the monetary benefits are received by public entities through a tax schedule. This policy instrument should reflect the environmental indicators for sustainable palm oil production and secure the rights of local and poor people who depend heavily on forest ecosystems. In addition, it is also important to link up with the international carbon system in securing the economic incentives under $\mathrm{REDD}^{++}$schemes, particularly if the government and communities decide to conserve forest instead of converting them to oil palm plantation.

Acknowledgments We would like to thank Hans-Peter Weikard, Matthias Schröter, Roy Remme, and Morgan Mutoko for their constructive comments on the manuscript. This research has been made possible through ERC Grant 263027 (Ecospace).

Open Access This article is distributed under the terms of the Creative Commons Attribution 4.0 International License (http://crea tivecommons.org/licenses/by/4.0/), which permits unrestricted use, distribution, and reproduction in any medium, provided you give appropriate credit to the original author(s) and the source, provide a link to the Creative Commons license, and indicate if changes were made.

\section{References}

Abram NK, Meijaard E, Ancrenaz M et al (2014) Spatially explicit perceptions of ecosystem services and land cover change in forested regions of Borneo. Ecosyst Serv 7:116-127. doi:10. 1016/j.ecoser.2013.11.004

Agus F, Runtunuwu E, June T et al (2009) Carbon dioxide emission in land use transition to plantation. J Litbang Pertan 28:119-126

Agus F, Gunarso P, Sahardjo BH et al (2010) Historical $\mathrm{CO}_{2}$ emissions from land use and land use change from the oil palm industry in Indonesia, Malaysia and Papua New Guinea. In: Killen TJ, Goon J (eds) Kuala Lumpur, pp 65-88

Agus F, Henson I, Sahardjo BH et al (2013) Review of emission factors for assessment of $\mathrm{CO}_{2}$ emission from land use change to oil palm in Southeast Asia. In: Killen TJ, Goon J (eds) Report from the technical panels of the second RSPO GHG working group. Roundtable on Sustainable Palm Oil, Kuala Lumpur

Azhar B, Lindenmayer DB, Wood J et al (2014) Ecological impacts of oil palm agriculture on forest mammals in plantation estates and smallholdings. Biodivers Conserv 23:1175-1191. doi:10. 1007/s10531-014-0656-z

Bagstad KJ, Villa F, Batker D et al (2014) From theoretical to actual ecosystem services: mapping beneficiaries and spatial flows in ecosystem service assessments. Ecol Soc. doi:10.5751/ES06523-190264

Boer R, Nurrochmat DR, Purwawangsa H, Ginting G (2012) Reducing agricultural expansion into forests in Central Kalimantan Indonesia: analysis of implementation and financing gaps. Bogor Agricultural University, Bogor

Boyd J, Banzhaf S (2007) What are ecosystem services? The need for standardized environmental accounting units. Ecol Econ 63:616-626. doi:10.1016/j.ecolecon.2007.01.002

Broich M, Hansen M, Stolle F et al (2011a) Remotely sensed forest cover loss shows high spatial and temporal variation across Sumatera and Kalimantan, Indonesia 2000-2008. Environ Res Lett 6:014010. doi:10.1088/1748-9326/6/1/014010

Broich M, Hansen MC, Potapov P et al (2011b) Time-series analysis of multi-resolution optical imagery for quantifying forest cover loss in Sumatra and Kalimantan, Indonesia. Int J Appl Earth Obs Geoinform 13:277-291. doi:10.1016/j.jag.2010.11.004

Balai Taman Nasional Tanjung Puting (BTNTP) (2012) Analisis ekonomi kegiatan wisata alam di Taman Nasional Tanjung Puting. Balai Besar Taman Nasional Tanjung Puting. Kalimantan Tengah, Indonesia

Budidarsono S, Susanti A, Zoomers A (2013) Oil palm plantations in Indonesia : the implications for migration, settlement/resettlement and local economic development. INTECH. doi:10.5775/5358

Budiningsih K, Effendi R (2013) Financial analysis Jelutung (Dyera polyphylla) forest plantation in Central Kalimantan. Jurnal Penelitian Hutan Tanaman 10(1):17-23

Carlson KM, Curran LM, Asner GP et al (2012a) Carbon emissions from forest conversion by Kalimantan oil palm plantations. Nat. Clim, Chang

Carlson KM, Curran LM, Asner GP et al (2012b) Carbon emissions from forest conversion by Kalimantan oil palm plantations. Nat Clim Chang 3:283-287. doi:10.1038/nclimate1702

Carlson KM, Curran LM, Ratnasari D et al (2012c) Committed carbon emissions, deforestation, and community land conversion from oil palm plantation expansion in West Kalimantan, Indonesia. Proc Natl Acad Sci 109:7559-7564

Couwenberg J, Hooijer A (2013) Towards robust subsidence-based soil carbon emission factors for peat soils in south-east Asia, with special reference to oil palm plantations. Mires Peat 12:1-13

Daily GC, Polasky S, Goldstein J et al (2009) Ecosystem services in decision making: time to deliver. Front Ecol Environ 7:21-28. doi:10.1890/080025

De Jong W (1995) Recreating the forest: successful examples of ethnoconservation among Dayak groups in Central West Kalimantan. In: Sandbukt O (ed) Management of tropical forests: towards an integrated perspective. University of Oslo, Centre for Development and the Environment, Oslo, Norway, pp 295-304

Dehen YA, Mustajab MM, Setiawan B, Anindita R (2013) Sustainability analysis of palm oil plantation in central Kalimantan province, Indonesia. J Econ Sustain Dev 6:175-183

Edens B, Hein L (2013) Towards a consistent approach for ecosystem accounting. Ecol Econ 90:41-52. doi:10.1016/j.ecolecon.2013. 03.003

Fisher B, Turner K, Zylstra M et al (2008a) Ecosystem services and economic theory: integration for policy-relevant research. Ecol Appl 18:2050-2067 
Fisher B, Turner RK, Morling P (2008b) Defining and classifying ecosystem services for decision making. Ecol Econ 68:643-653. doi:10.1016/j.ecolecon.2008.09.014

Germer J, Sauerborn J (2007) Estimation of the impact of oil palm plantation establishment on greenhouse gas balance. Environ Dev Sustain 10:697-716. doi:10.1007/s10668-006-9080-1

Gunarso P from the TP of the 2nd GGWG of the R on SPO(R), Eko Hartoyo M, Agus F, Killen TJ (2013) Oil palm and land use change in Indonesia, Malaysia and Papua New Guinea. In: Killen TJ, Goon J (eds) Reports from the technical panels of the 2nd greenhouse gas working group of the Roundtable on Sustainable Palm Oil (RSPO). pp 29-64

Hadi A, Fatah L, Affandi DN (2012) Greenhouse gas emissions from peat soils cultivated to rice field. Oil Palm Veg. 17:105-114. doi:10.5400/jts.2012.17.2.105

Haines-young R, Potschin M (2013) Common international classification of ecosystem services (CICES): consultation on version 4. University of Nottingham, UK

Harrington R, Anton C, Dawson TP et al (2010) Ecosystem services and biodiversity conservation: concepts and a glossary. Biodivers Conserv 19:2773-2790. doi:10.1007/s10531-010-9834-9

Hein L, van Koppen K, de Groot RS, van Ierland EC (2006) Spatial scales, stakeholders and the valuation of ecosystem services. Ecol Econ 57:209-228. doi:10.1016/j.ecolecon.2005.04.005

Hein L, Obst C, Edens B, Remme RP (2015) Progress and challenges in the development of ecosystem accounting as a tool to analyse ecosystem capital. Curr Opin Environ Sustain 14:86-92. doi:10. 1016/j.cosust.2015.04.002

Herman AF, Las I (2009) Analisis finansial dan keuntungan yang hilang dari pengurangan emisi karbon dioksida pada perkebunan kelapa sawit. J Litbang Pertan 28:127-133

Hernández-Morcillo M, Plieninger T, Bieling C (2013) An empirical review of cultural ecosystem service indicators. Ecol Indic 29:434-444. doi:10.1016/j.ecolind.2013.01.013

Hooijer A, Page S, Canadell JG et al (2010) Current and future $\mathrm{CO}_{2}$ emissions from drained peatlands in Southeast Asia. Biogeosciences 7:1505-1514. doi:10.5194/bg-7-1505-2010

Hooijer A, Page S, Jauhiainen J et al (2012) Subsidence and carbon loss in drained tropical peatlands. Biogeosciences 9:1053-1071. doi:10.5194/bg-9-1053-2012

Howe C, Suich H, Vira B, Mace GM (2014) Creating win-wins from trade-offs? Ecosystem services for human well-being: a metaanalysis of ecosystem service trade-offs and synergies in the real world. Glob Environ Chang 28:263-275. doi:10.1016/j.gloenv cha.2014.07.005

Iksan S, Abdussamad (2010) Feasibility analysis of community oil palm plantation development in Tanah Laut District, South Kalimantan. Agroscientiae 3(1):111-116

Interagency Working Group on Social Cost of Carbon (2013) Technical support document: technical update of the social cost of carbon for regulatory impact analysis. United States Government

Inubushi K, Furukawa Y, Hadi A et al (2003) Seasonal changes of $\mathrm{CO}(2), \mathrm{CH}(4)$ and $\mathrm{N}(2) \mathrm{O}$ fluxes in relation to land-use change in tropical peatlands located in coastal area of South Kalimantan. Chemosphere 52:603-608. doi:10.1016/S0045-6535(03)00242-X

Ismail R (2010) Analisa kelayakan finansial proyek prmbangunan kebun kelapa sawit pola revilatisai perkebunan dan pabrik pengolahannya atas nama PT. AUS, Bogor

Iwan (2008) Analisis finansial agroforetri rotan di Teluk Teweh, Kotawaringin Timur. Palangkaraya, Indonesia

Kettunen M, Bassi S, Gantioler S, ten Brink P (2009) Assessing Socio-economic benefits of natura 2000-a toolkit for practitioners (September 2009 edition). Output of the European Commission project Financing Natura 2000: cost estimate and benefits of Natura 2000 (Contract No.: 070307/2007/484403/ MAR/B2). Brussel, Belgium

Koh LP, Miettinen J, Liew SC, Ghazoul J (2011) Remotely sensed evidence of tropical peatland conversion to oil palm. Proc Natl Acad Sci USA 108:5127-5132. doi:10.1073/pnas.1018776108

Lambin EF, Geist HJ, Lepers E (2003) D Ynamics of L and -U Se and $\mathrm{L}$ and $-\mathrm{C}$ Over $\mathrm{C}$ Hange in $\mathrm{T}$ Ropical $\mathrm{R}$ Egions. Annu Rev Environ Resour 28:205-241. doi:10.1146/annurev.energy.28. 050302.105459

Larsen RK, Osbeck M, Jiwan N et al (2012) Competing water claims in biofuel feedstock operations in central Kalimantan. Stockholm, Sweden

Law EA, Bryan BA, Meijaard E et al (2014) Ecosystem services from a degraded peatland of Central Kalimantan: implications for policy, planning and management. Ecol Appl 25:70-87

Leh MDK, Matlock MD, Cummings EC, Nalley LL (2013) Quantifying and mapping multiple ecosystem services change in West Africa. Agric Ecosyst Environ 165:6-18. doi:10.1016/j.agee. 2012.12.001

Lim K, Lim S, Parish H, Suharto R (2012) RSPO manual on best management practices (BMPs) for existing oil palm cultivation on peat. Kuala Lumpur, Malaysia

Martoniady (2009) Kontribusi rotan terhadap pendapatan petani di Tumbang Talakan, Central Kalimantan. Palangkaraya, Indonesia

McCarthy JF, Cramb RA (2009) Policy narratives, landholder engagement, and oil palm expansion on the Malaysian and Indonesian frontiers. Geogr J 175:112-123. doi:10.1111/j.14754959.2009.00322.x

McCarthy JF, Gillespie P, Zen Z (2012) Swimming upstream: local indonesian production networks in "globalized" palm oil production. World Dev 40:555-569. doi:10.1016/j.worlddev. 2011.07.012

Meijaard E, Abram NK, Wells JA et al (2013) People's perceptions about the importance of forests on Borneo. PLoS ONE 8:e73008. doi:10.1371/journal.pone. 0073008

Millennium Ecosystem Assessment (MA) (2005) Ecosystem and human well-being: synthesis. Island Press, Washington DC

Ministry of Forestry (2011) Forest statistic book. Ministry of Forestry, Jakarta, Indonesia

Nahlik AM, Kentula ME, Fennessy MS, Landers DH (2012) Where is the consensus? A proposed foundation for moving ecosystem service concepts into practice. Ecol Econ 77:27-35. doi:10.1016/ j.ecolecon.2012.01.001

Nellemann C, Milles L, Kaltenborn B et al (2007) The last stand of the Orangutan - state of emergency: Illegal logging, fire and palm oil in Indonesia's national parks. UN Environmenta Programme, GRID-Arendal, Arendal

Nugroho M (2008) Analisis efficiensi padi pasang surut dan lahan kering di kecamatan Arut Selatan. Kabupaten Kotawaringin Barat, Palangkaraya

Obidzinski K, Andriani R, Komarudin H, Andrianto A (2012) Environmental and social impacts of oil palm plantations and their implications for biofuel production in Indonesia. Ecol Soc. $17: 25$

Obst C, Hein L, Edens B (2015) National accounting and the valuation of ecosystem assets and their services. Environ Resour Econ. doi:10.1007/s10640-015-9921-1

Palupi S (2014) Palm oil industry and human rights: a case study on oil palm corporations in central Kalimantan. The Institute for Ecosoc Rights. Jakarta. Indonesia

Paoli GD, Wells PL, Meijaard E et al (2010) Biodiversity conservation in the REDD. Carbon Balance Manag 5:7. doi:10.1186/ 1750-0680-5-7

Plieninger T, Dijks S, Oteros-Rozas E, Bieling C (2013) Assessing, mapping, and quantifying cultural ecosystem services at 
community level. Land Use Policy 33:118-129. doi:10.1016/j. landusepol.2012.12.013

Potter L (2012) New transmigration "paradigm" in Indonesia: examples from Kalimantan. Asia Pac Viewp 53:272-287. doi:10.1111/j.1467-8373.2012.01492.x

Rastogi A, Badola R, Hussain SA, Hickey GM (2010) Assessing the utility of stakeholder analysis to protected areas management: the case of Corbett National Park, India. Biol Conserv 143:2956-2964. doi:10.1016/j.biocon.2010.04.039

Rist L, Feintrenie L, Levang P (2010) The livelihood impacts of oil palm: smallholders in Indonesia. Biodivers Conserv 19:1009-1024. doi:10.1007/s10531-010-9815-z

Rodríguez JP, Beard TD, Bennett EM et al (2006) Trade-offs across space, time, and ecosystem services. Ecol Soc 11:28

Sanchez PA (2000) Linking climate change research with food security and poverty reduction in the tropics. Agric Ecosyst Environ 82:371-383. doi:10.1016/S0167-8809(00)00238-3

Sapiudin (2009) Kontribusi peyadapan getah jelutung rawa (Dyera pollyphylla Miq. Steenis) terhadap pendapatan masayarakat di desa Kubu, kecamatan Kumai, kabupaten Kotawaringin Barat. Faculty of Forestry, Lambung Mangkurat University

Setiawan B, Wessiani N, Andrian Y (2011) Perancangan SOP dan biaya standard untuk melihat pencapaian target perusahaan terhadap Rencana Kerja Tahunan (RKT) HPH di PT.X. Surabaya, Indonesia

Sirait M (2009) Indigenous peoples and oil palm plantation expansion in West Kalimantan, Indonesia. Universiteit van Amstedam and Cordaid Memisa. The Netherlands

Sumarga E, Hein L (2014) Mapping ecosystem services for land use planning, the case of Central Kalimantan. Environ Manag 54:84-97. doi:10.1007/s00267-014-0282-2

Sumarga E, Hein L, Edens B, Suwarno A (2015) Mapping monetary values of ecosystem services in support of developing ecosystem accounts. Ecosyst Serv 12:71-83. doi:10.1016/j.ecoser.2015.02.009
Suyanto, Khususiyah N, Sardi I et al (2009) Analysis of local livelihoods from past to present in the Central Kalimantan exmega rice project area. Bogor, Indonesia

TEEB (2010) The economics of ecosystems and biodiversity: ecological and economic foundations. Earthscan, London and Washington

Tilman D, Cassman KG, Matson PA et al (2002) Agricultural sustainability and intensive production practices. Nature 418:671-677. doi:10.1038/nature01014

Tol RSJ (2005) The marginal damage costs of carbon dioxide emissions: an assessment of the uncertainties. Energy Policy 33:2064-2074. doi:10.1016/j.enpol.2004.04.002

Tomich TP, Thomas DE, Van Noordwijk M (2004) Environmental services and land use change in Southeast Asia: from recognition to regulation or reward? Agric Ecosyst Environ 104:229-244. doi:10.1016/j.agee.2004.01.017

United Nation (UN), European Union, Food and Agriculture Organization of the United Nations, International Monetary Fund, Organisation for Economic Co-operation and Development, The World Bank (2014) System of environmental and economic accounting 2012: Central framework. United Nation, New York

Whitten T, van Dijk P, Meijaard L et al (2004) Hotspots revisited: another look at earth's richest and most endangered terrestrial ecoregions. Cemex, Mexico

Wich SA, Meijaard E, Marshall AJ et al (2008) Distribution and conservation status of the orang-utan (Pongo spp.) on Borneo and Sumatra : how many remain? Oryx 42:329-339

Yamamoto Y, Takeuchi K (2012) Estimating the break-even price for forest protection in Central Kalimantan. Environ Econ Policy Stud 14:289-301. doi:10.1007/s10018-012-0030-x

Yandi A (2008) Analisis finansial pengusahaan padi di kecamatan Kuala Kurun, kabupaten Gunung Mas. Palangkaraya, Indonesia 